\title{
NUTRITIONAL VALUE AND SENSORY DESCRIPTION OF "ATADJON BASSAMOIS", A TRADITIONAL INFANTILE PORRIDGE BASED ON TIGERNUT (CYPERUS ESCULENTUS, L.)
}

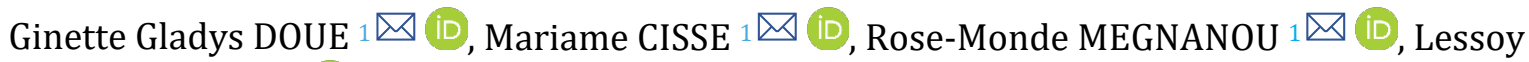 \\ Thierry ZOUE $1 \bowtie$ (iD)
}

${ }^{1}$ Laboratory of Biotechnology, Agriculture and Valorization of Biological Resources (UPR of Biotechnologies), Biosciences Faculty, Félix Houphouët-Boigny University, 22 BP 582 Abidjan 22, Côte d'Ivoire.

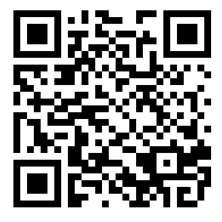

\section{ABSTRACT}

Child malnutrition is still a public health problem in Côte d'Ivoire, mainly due to poor feeding practice linked to the low nutritional value of the staple foods used for child nutrition. However, the introduction of tigernut, proteins and lipids rich tuber, in the dietary habits of these children could constitute an interesting nutritional alternative to solve this problem. The objective of this work was to valorize the tigernut-based porridges for their use as complementary food in the diet of weaning children. To this end, physicochemical and organoleptic characteristics of four formulations AB1, AB4, RB2 and SB3 were studied. The atadjon formulations, especially AB1, presented the

Received 3 November 2021

Accepted 14 December 2021

Published 31 December 2021

\section{CorrespondingAuthor}

Ginette Gladys DOUE,

gladysdoue@yahoo.com

DOI

10.29121/granthaalayah.v9.i12.2021 .4421

Funding: This research received no specific grant from any funding agency in the public, commercial, or not-for-profit sectors.

Copyright: (C) 2021 The Author(s). This is an open access article distributed under the terms of the Creative Commons Attribution License, which permits unrestricted use, distribution, and reproduction in any medium, provided the original author and source are credited.

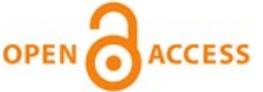
highest density in energy (95.70 Kcal/100g), protein (5.37\%), lipids (3.8\%) and the lowest contents in anti-nutrients with $2.17 \%$ in fiber, $36.6 \%$ in oxalates, $65.54 \%$ in tannin and $0 \%$ in phytates, contrary to the rice (RB2) and tigernut (SB3) control porridges. In addition, the atadjon formulations $\mathrm{AB} 4$ and $\mathrm{AB} 1$ were preferred to the control because of their sweet taste, tigernut flavor, brown color and flowability according to PCA analysis. Thus, this study indicates that these traditionally prepared porridges could be suitable for children receiving an average level of breastfeeding and three meals per day.

Keywords: Infant Malnutrition, Complementary Foods, Traditional Porridges, Côte D'ivoire.

\section{INTRODUCTION}

Tigernut (Cyperus esculentus L.) is an herbaceous plant found throughout the African continent where it has been domesticated and is used as a food plant. Its crop is widespread in North Africa and particularly in West Africa in countries such as Ghana, Nigeria, Niger, Burkina Faso, Mali and Côte d'Ivoire Defelice (2002). Described as a food plant with high dietary value Linssen et I. (1988), its tubers are known to be rich in energy (starch, fat, sugars and proteins), minerals (phosphorus, potassium) and vitamins E and C Belewu and Belewu (2007). Despite all these potentialities, tigernuts remain insufficiently exploited in terms of food due to its lack of knowledge and the little interest it arouses among populations who have long considered it like a weed Koffi et al. (2005).

However, the presence of trace elements (minerals and vitamins), macronutrients (carbohydrates, lipids and proteins) and essential amino acids Koffi et al. (2005), Belewu and Belewu (2007) in this tuber make it a food of nutritional interest. Still little used but available at a lower cost, this tuber has the potential to improve the nutritional status of the most vulnerable segments of the population and could therefore contribute to food security. Thus, the integration 
of this local resource in the diets of these populations could constitute a sustainable food approach to fight against public health problems of nutritional origin such as malnutrition Toledo and Burlingame (2006).

Malnutrition is a scourge that affects all segments of the population, particularly children in developing countries. In these countries, it mainly takes the form of deficit malnutrition (chronic malnutrition, acute malnutrition, micronutrient deficiencies). This form of protein-energy malnutrition affects children under five years of age mainly during the complementary feeding period. It accounts for at least half of all child deaths Black et al. (2013), Dolan et al. (2015). From the age of 6 months, breast milk becomes qualitatively and quantitatively insufficient to cover the growing nutritional needs of the infant. It is therefore necessary to introduce new foods in liquid or semi-liquid form to supplement the intake of breast milk. This period constitutes a high-risk phase in the life of infants, because if poorly conducted, complementary feeding leads to multi-carrier malnutrition, which is one of the crucial health problems in infants Azagoh et al. (2013), Victora et al. (2016) .

In developing countries, mothers most often use traditional root or tuber-based porridges as weaning food, products that are rich in starch Trêche et al. (1993) but poor in protein. These traditional porridges are generally low in micronutrient and energy density. In addition, the consumption rate of these porridges is low, especially in rural areas where mothers give only two meals per day instead of the recommended minimum of three Trêche et al. (1993) usually practiced in urban areas Trèche (2004).

Although a tuber, sweet tigernut has a higher fat, protein and carbohydrate (including fiber and starch) content than tubers Mogaji (2016) and may therefore be suitable for porridge preparation (complementary food) for weaning-age infants. In Côte d'Ivoire, and particularly in the Bassam region, porridges prepared from a mixture of tigernut and rice are given as a complementary food to breast milk to infants aged 6 to 24 months. These porridges called atadjon, usually prepared in proportions of $2 / 3-1 / 3$, or $1 / 2-1 / 2$ in tigernuts and rice, respectively are also popular with young children and adults. No study has been done to date to evaluate the nutritional potential of these souchet-based porridges. However, such a study would not only highlight the nutritional potential of these porridges, but also identify the appropriate formulation for complementary feeding of infants. It is in this context that the general objective of this work is to valorize the tigernut-based porridges (atadjon) for their use as complementary food for infants.

\section{MATERIALS AND METHODS}

\subsection{MATERIAL}

The plant material used in this work consists of rice (Oryza sativa) and tigernuts (Cyperus esculentus L.) purchased on the market of Adjamé (Abidjan).

\subsection{ANALYTICAL METHODS}

\subsubsection{PORRIDGE PREPARATION}

The different porridges were prepared according to the rural method used by women in the Grand Bassam region (Côte d'Ivoire). This method consists in making a milk of rice and tigernuts in determined proportions which will be used for the preparation of the porridge. Four porridges were prepared including two control porridges, $100 \%$ Tigernuts $\left(\mathrm{SB}_{3}\right)$ and $100 \%$ rice, $\left(\mathrm{RB}_{2}\right)$ and two atadjon porridges $\left(\mathrm{AB}_{4}\right)$ with equal amounts of rice and Tigernuts and $\left(\mathrm{AB}_{1}\right)$ with $2 / 3$ Tigernuts and 
$1 / 3$ rice Figure 1 . Thus, after weighing the grains (tigernuts and rice), a manual sorting is performed to remove impurities and defective grains. These grains were then washed carefully with distilled water at least three times (until clear rinsing water is obtained). After soaking in distilled water for 24 hours, the grains were ground into a paste using a Blender (Moulinex, France). This paste is then diluted in $500 \mathrm{~mL}$ of distilled water and filtered 3 or 4 times. The milk obtained is collected in a stainless-steel pan and cooked over a low heat for 5 minutes to obtain the porridge.

\subsubsection{DETERMINATION OF THE PORRIDGE'S PROXIMATE CHARACTERISTICS}

The nutritional content of porridges was evaluated by the analysis of their proximate composition like dry matter content, $\mathrm{pH}$ and titratable acidity, ash content in the dry method, crude protein $(\mathrm{N} \times 6.25)$ content by Kjeldahl method in triplicate according to the Standard Association of Official Analytical Chemists procedures AOAC (1990). Total Lipids content was performed by the cold extraction method in chloroform-methanol (v/v) according to Folch et al. (1957). Total sugar content was determined by the phenol-sulfuric method as described by Dubois et al. (1956) after ethanosoluble extraction performed from the method described by Dubois et al. (1956). AOAC (1980) was used for the determination of minerals using an atomic absorption spectrophotometer. Total carbohydrate content of foods was calculated by difference according to the method recommended by the FAO (2002) and The energy value of the porridge samples was calculated on the basis of the energy coefficients defined by the FAO (2002) according to the following formula : $\boldsymbol{V} \boldsymbol{E}(\mathrm{kcal} / 100 \mathrm{~g})=4 \times \mathrm{C}(\%)+9 \times \mathrm{L}(\%)+4 \times \mathrm{P}(\%)$ VE, C, L and P refer to the energy value, carbohydrate, lipid and protein contents respectively. The starch content was determined by considering the starch/glucose ratio as 0.9 by formula (1) according to Atwater and Benedict (1902) procedure, Amidon = $0.9 \times$ (\%carbohydrates \%total sugar) (1)

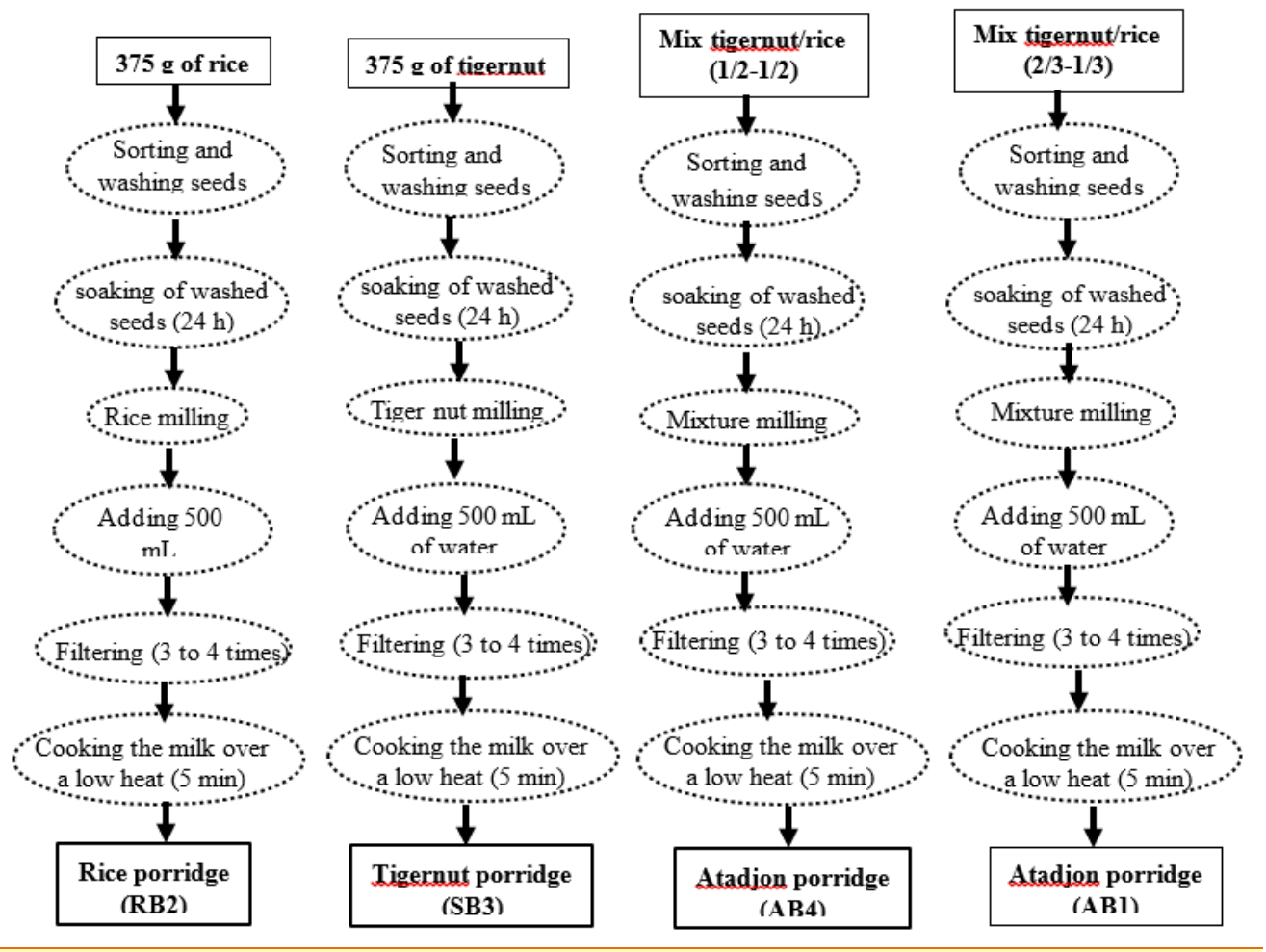

Figure 1 Process flowchart on the preparation of porridges 


\subsubsection{DETERMINATION OF THE PORRIDGES ANTI- NUTRITIONAL FACTORS \\ 2.2.3.1. TANNIN'S CONTENT}

After extraction of phenolic compounds with methanol following the method of Singleton et al. (1999), the tannins content was carried out in sulfuric acid medium with vanillin according to the method described by Bainbridge et al. (1996). The number of tannins in the samples was determined using a standard curve established from a stock solution of tannic acid $(2 \mathrm{mg} / \mathrm{mL})$ under the same conditions as the test.

\subsubsection{PHYTIC ACID CONTENT}

The phytic acid content of each sample was determined according to methods AOAC (2005). Five grams from each porridge was weighted into a $500 \mathrm{~mL}$ conical flask and soaked in $250 \mathrm{~mL}$ of $2 \%$ hydrochloric acid $(\mathrm{HCl})$ for $3 \mathrm{~h}$. After filtration (wathman \#4) of the mixture, $5 \mathrm{~mL}$ of the filtrate was added to $100 \mathrm{~mL}$ of distilled water and $10 \mathrm{~mL}$ of a $0.3 \%$ ammonium thiocyanate $\left(\mathrm{NH}_{4} \mathrm{SCN}\right)$ solution and the mixture titrated against standard ferric chloride $(0.00195 \mathrm{~g} \mathrm{Fe} / \mathrm{mL})$ until the color changed to a stable, slightly brownish yellow over $4 \mathrm{~min}$. The phytate content was calculated as follows: Eq (2): Phytates (\%) $=(\mathrm{T} \times 1.19 \times 100) / 0.00195(2)$ Where $\mathrm{T}$ is the volume of the titre.

\subsubsection{OXALATES CONTENT}

Oxalates content was determined by the methods descibed by Day and Underwood (1986). $1 \mathrm{~mL}$ from each porridge and $75 \mathrm{~mL}$ of $3.0 \mathrm{~mol} / \mathrm{L} \mathrm{H}_{2} \mathrm{SO}_{4}$ were carefully stirred for an hour and filtered (Wathman $\mathrm{n}^{\circ} 1$ ). $5 \mathrm{~mL}$ of filtrate was titrated against hot $\left(80-90^{\circ} \mathrm{C}\right) 0.1 \mathrm{~mol}^{\mathrm{L}} \mathrm{L}^{-1} \mathrm{KMnO}_{4}$ until the point where a faint pink colour appeared and persisted for at least $30 \mathrm{~s}$.

\subsubsection{SENSORY CHARACTERISTICS OF THE COMPLEMENTARY PORRIDGES.}

\subsubsection{ACCEPTABILITY AND GRADING TESTS OF PORRIDGES}

A panel of 50 untrained individuals (young girls and boys, adult women and men) was formed and recruited on the basis of their availability Ruwaida et al. (2016). Coded (with 3 digits) samples of the porridges were presented simultaneously to each panelist in a randomized order. Each panelist's perceived enjoyment was scored on a 5 -point hedonic scale. Scores ranging from 5 (very good) to 1 (very bad) were assigned to the different scale modalities.

\subsubsection{QUANTITATIVE DESCRIPTIVE ANALYSIS}

The method consists of evaluating and quantifying the appropriate descriptors (smell, taste, consistency, color and texture) according to a category scale Meilgaard et al. (2007). The prepared porridges were presented to a panel of 10 people recruited and trained in the analysis methodology. These porridges were presented simultaneously in a randomized order, in coded containers (with 3 digits) each accompanied by a glass of water and a spoon. Each taster receives four porridges, two control porridges $\left(\mathrm{RB}_{2}, 100 \%\right.$ rice and $\mathrm{SB}_{3}, 100 \%$ tigernut), and two mixed atadjon porridges $\left(\mathrm{AB}_{4}, 1 / 2-1 / 2\right)$ and $\left(\mathrm{AB}_{1}, 2 / 3-1 / 3\right)$ of a tigernut-rice mixture, 
respectively. Preliminary instructions and explanations are given to the tasters before the tasting. They focus on the descriptors of organoleptic properties of the porridges as well as the scores assigned to them.

\subsection{STATISTICAL ANALYSIS}

All trials are performed in triplicate and results are expressed as mean \pm standard deviation. The analysis of variance (ANOVA) is performed using XLSTAT 2014. The test at the $95 \%$ level is used to determine the significant differences between the means. Principal component analysis (PCA) was performed using XLSTAT software to look for systematic variations in sensory descriptors.

\section{RESULTS}

\subsection{NUTRIENT DENSITY OF COMPLEMENTARY PORRIDGES}

\subsubsection{ENERGY AND MACRONUTRIENT DENSITY}

Statistical analysis of the nutritional characteristics of the two control porridges $\mathrm{RB}_{2}\left(100 \%\right.$ rice) and $\mathrm{SB}_{3}(100 \%$ tigernut) as well as the atadjon porridges $A_{1}$ (2/3 tigernut) and $A_{4}(1 / 2$ tigernut) showed that overall, these porridges differ from each other $(\mathrm{p}<5 \%)$ Table 1.

\begin{tabular}{|c|c|c|c|c|c|c|}
\hline porridge & DM (\%) & Ash (g) & Fat (g) & Protein (g) & carbohyd(g) & $\begin{array}{c}\text { Energy } \\
\text { (Kcal) }\end{array}$ \\
\hline $\mathrm{RB}_{2}$ & $12.00 \pm 0.09 \mathrm{~d}$ & $\underline{00.90 \pm 0.01 \mathrm{~d}}$ & $\underline{01.50 \pm 0.02 \mathrm{~d}}$ & $\underline{02.28 \pm 0.08 \mathrm{~d}}$ & $07.32 \pm 0.14 c$ & $51.90 \pm 0.06^{d}$ \\
\hline $\mathrm{SB}_{3}$ & $14.60 \pm 0.05^{c}$ & $02.40 \pm 0.01^{\mathrm{a}}$ & $03.40 \pm 0.01^{b}$ & $02.70 \pm 0.05^{c}$ & $\underline{06.10 \pm 0.02 \mathrm{~d}}$ & $65.80 \pm 0.30^{c}$ \\
\hline $\mathrm{AB}_{4}$ & $15.00 \pm 0.02^{b}$ & $01.30 \pm 0.01^{c}$ & $03.20 \pm 0.02^{c}$ & $04.50 \pm 0.07 \mathrm{~b}$ & $09.10 \pm 0.12^{b}$ & $83.20 \pm 0.02^{b}$ \\
\hline $\mathrm{AB}_{1}$ & $21.00 \pm 0.05^{a}$ & $01.90 \pm 0.05^{b}$ & $03.80 \pm 0.01^{a}$ & $05.37 \pm 0.04^{a}$ & $10.01 \pm 0.07^{a}$ & $95.70 \pm 0.12^{a}$ \\
\hline \multicolumn{7}{|c|}{$\begin{array}{l}\text { High values are in bold and low values are underlined. The values of the same column affected by different } \\
\text { alphabetical letters are significantly different according to the Duncan test at the } 5 \% \text { threshold; those } \\
\text { affected by the same letter are not. DM: dry matter. Atadjon porridges AB1 }(1 / 3-2 / 3 \text {, rice/tigernuts), AB4 } \\
(1 / 2-1 / 2 \text {, rice/tigernuts), rice control RB2 (100\% rice) and tigernut control SB1 (100\% tigernuts) }\end{array}$} \\
\hline
\end{tabular}

With regard to the $\mathrm{DM}$, the two atadjon porridges showed the highest contents with $\mathrm{AB}_{1}(21 \%)$ and $\mathrm{AB}_{4}(15 \%)$ in contrast to the reference porridges rice $\mathrm{RB}_{2}(12$ $\%$ ) and tigernuts $\mathrm{SB}_{3}(14.60 \%)$. The same trend was also observed for lipid content with 3.80 and $3.20 \%$, protein content with 5.37 and $4.50 \%$, carbohydrate content with 10.01 and $9.10 \%$, energy value with 95.70 and $83.20 \mathrm{Kcal}$ for these two atadjon porridges $\mathrm{AB}_{1}$ and $\mathrm{AB}_{4}$, respectivly. Furthermore, it is worth noting that the atadjon porridge $A_{1}$ had the highest content for these parameters.

On the other hand, in the case of the ash content, although the $\mathrm{RB}_{2}$ rice porridge $(2.40 \mathrm{~g} / 100 \mathrm{~g})$ recorded the highest content, the two atadjon $\mathrm{AB}_{4}$ and $\mathrm{AB}_{1}$ porridges recorded intermediate ash values of 1.30 and $1.90 \mathrm{~g} / 100 \mathrm{~g}$, respectively.

\subsubsection{MINERAL DENSITY OF THE COMPLEMENTARY PORRIDGES}

The results concerning the main studied macro and oligo minerals of the complementary porridges have been consigned in the Table 2. Minerals contents in all the studied porridges were significantly different from each other at $\mathrm{p}<0.05$. 
Table 2 Density of the main minerals in the complementary porridges in mg per $100 \mathrm{~g}$ of porridge

\begin{tabular}{|c|c|c|c|c|c|c|c|}
\hline \multirow[t]{2}{*}{ Porridges } & \multicolumn{4}{|c|}{ Macro minerals } & \multicolumn{3}{|c|}{ Oligo minerals } \\
\hline & $\mathbf{P}(\mathrm{mg})$ & $\mathbf{K}(\mathrm{mg})$ & Ca (mg) & Mg (mg) & $\mathbf{F e}(\mathrm{mg})$ & Na (mg) & Zn (mg) \\
\hline $\mathrm{RB}_{2}$ & $24.72 \pm 0.0^{\mathrm{d}}$ & $024.70 \pm 0.1^{\mathrm{d}}$ & $11.02 \pm 0.0^{\mathrm{d}}$ & $15.20 \pm 0.0^{\mathrm{d}}$ & $2.67 \pm 0.1^{d}$ & $20.32 \pm 0.2^{\mathrm{d}}$ & $1.17 \pm 0.1^{\mathrm{d}}$ \\
\hline $\mathrm{SB}_{3}$ & $26.16 \pm 0.0^{c}$ & $127.37 \pm 0.2^{b}$ & $42.07 \pm 0.1^{a}$ & $38.00 \pm 0.0^{b}$ & $9.79 \pm 0.1^{b}$ & $93.87 \pm 0.0^{a}$ & $3.77 \pm 0.1^{\mathrm{a}}$ \\
\hline $\mathrm{AB}_{4}$ & $35.72 \pm 0.0^{b}$ & $104.03 \pm 0.2^{c}$ & $15.17 \pm 0.0^{c}$ & $34.23 \pm 0.0^{c}$ & $4.79 \pm 0.0^{c}$ & $36.74 \pm 0.0^{c}$ & $1.41 \pm 0.0^{c}$ \\
\hline $\mathrm{AB}_{1}$ & $38.03 \pm 0.0^{a}$ & $165.94 \pm 0.0^{a}$ & $30.91 \pm 0.0^{\mathrm{b}}$ & $39.33 \pm 0.1^{a}$ & $7.11 \pm 0.0^{a}$ & $68.22 \pm 0.0^{\mathrm{b}}$ & $3.25 \pm 0.1^{b}$ \\
\hline
\end{tabular}

High values are in bold and low values are underlined. The values of the same column affected by different alphabetical letters are significantly different according to the Duncan test at the $5 \%$ threshold; those affected by the same letter are not. Atadjon porridges $A B 1$ (1/3-2/3, rice/tigernuts), $A B 4$ (1/2-1/2, rice/tigernuts), rice control RB2 (100\% rice) and tigernut control SB1 (100\% tigernuts)

Regarding macro minerals, while for $\mathrm{P}, \mathrm{K}$, and $\mathrm{Mg}$ the atadjon porridges $\mathrm{AB}_{1}$ and $\mathrm{AB}_{4}$ have the highest contents, for Ca on the contrary it is the yellow tigernuts control porridge $\mathrm{SB}_{3}$ that stands out with the highest content $(42.07 \mathrm{mg} / 100 \mathrm{~g})$. Similarly, in the case of oligominerals, these two atadjon porridges $A B_{1}$ and $A B_{4}$ stand out with the highest iron content for $\mathrm{AB}_{1}(7.11 \mathrm{mg} / 100 \mathrm{~g})$ and intermediate contents for $\mathrm{Zn}(3.25$ and $1.41 \mathrm{mg} / 100 \mathrm{~g}$ ) and $\mathrm{Na}(68.22$ and $36.74 \mathrm{mg} / 100 \mathrm{~g}$ ) respectively for $A B_{1}$ and $A B_{4}$.

\subsection{PHYSICO-CHEMICAL COMPOSITION OF THE COMPLEMENTARY PORRIDGES}

Table 3 is related the result from the physico-chemical composition of the studied complementary porridges. Statistical analysis revealed significant differences in the mean values of the physicochemical parameters for all porridges except for fibers, where the rice control $\mathrm{RB}_{2}(1.63 \mathrm{~g} / 100 \mathrm{~g})$ and the atadjon porridge $\mathrm{AB}_{4}(1.67 \mathrm{~g} / 100 \mathrm{~g})$ showed the same values at $\mathrm{p}<0.05$.

Table 3 Starch, fiber, total sugars and pH, titratable acidity content of complementary porridges per $100 \mathrm{~g}$ of porridge

\begin{tabular}{cccccc}
\hline Porridges & Starch (g) & Fibers (g) & PH & T. A. (Eq) & S.T (g) \\
$\mathrm{RB}_{2}$ & $06.49 \pm 0.28^{\mathrm{c}}$ & $01.63 \pm 0.14^{\mathrm{c}}$ & $\mathbf{5 . 6 7 \pm 0 . 0 1 ^ { \mathrm { a } }}$ & $0.40 \pm 0.03^{\mathrm{d}}$ & $0.109 \pm 0.02^{\mathrm{d}}$ \\
$\mathrm{SB}_{3}$ & $05.17 \pm 0.10^{\mathrm{d}}$ & $\mathbf{0 3 . 1 6} \pm \mathbf{0 . 1 8 ^ { \mathrm { a } }}$ & $4.17 \pm 0.01^{\mathrm{d}}$ & $\mathbf{1 . 9 5}^{\mathrm{00.02}}{ }^{\mathrm{a}}$ & $\mathbf{0 . 3 6 2} \pm \mathbf{0 . 0 1}{ }^{\mathrm{a}}$ \\
$\mathrm{AB}_{4}$ & $07.99 \pm 0.24^{\mathrm{b}}$ & $01.67 \pm 0.10^{\mathrm{c}}$ & $4.86 \pm 0.01^{\mathrm{b}}$ & $1.12 \pm 0.04^{\mathrm{c}}$ & $0.216 \pm 0.01^{\mathrm{c}}$ \\
$\mathrm{AB}_{1}$ & $\mathbf{0 8 . 6 5} \pm \mathbf{0 . 1 6 ^ { \mathbf { a } }}$ & $02.17 \pm 0.10^{\mathrm{b}}$ & $4.28 \pm 0.02^{\mathrm{c}}$ & $1.20 \pm 0.06^{\mathrm{b}}$ & $0.321 \pm 0.01^{\mathrm{b}}$
\end{tabular}

High values are in bold and low values are underlined. The values of the same column affected by different alphabetical letters are significantly different according to the Duncan test at the $5 \%$ threshold; those affected by the same letter are not. $\mathrm{pH}$ : hydrogen potential, T.S.: total sugars, T.A.: titratable acidity. Atadjon porridges AB1 (1/3-2/3, rice/tigernuts), AB4 (1/2-1/2, rice/tigernuts), rice control RB2 (100\% rice) and tigernut control SB1 (100\% tigernuts)

Thus, it is important to note that the four investigated porridges showed values for $\mathrm{pH}$ and titratable acidity that are inversely correlated. When for the $\mathrm{pH}$, the control porridges recorded for $\mathrm{RB}_{2}$ (5.67) the highest value and $\mathrm{SB}_{3}$ (4.17) the lowest value, for the titratable acidity it is the opposite tendency which is drawn with the lowest value $(0.40 \mathrm{Eq} / 100 \mathrm{~g})$ and the highest value $(1.95 \mathrm{Eq} / 100 \mathrm{~g})$ respectively for these porridges.

On the other hand, if for the starch it is the atadjon porridges which exhibited the highest values namely $8.65 \mathrm{~g} / 100 \mathrm{~g}\left(\mathrm{AB}_{1}\right)$ and $7.99 \mathrm{~g} / 100 \mathrm{~g}\left(\mathrm{AB}_{4}\right)$ in the case of fibers and total sugars these porridges have on the contrary displayed the intermediate contents. 


\subsection{ANTI-NUTRITIVE PROPERTIES OF THE COMPLEMENTARY PORRIDGES}

The analysis of variance carried out on the anti-nutritive properties of the different studied porridges showed a significant difference at the 5\% threshold for oxalate and tannins, phytates being totally absent Table 4 .

\begin{tabular}{|c|c|c|c|}
\hline Porridges & Oxalate & Phytate & Tannins \\
\hline $\mathrm{RB}_{2}$ & $21.90 \pm 0.58 \mathrm{~d}$ & $00.00 \pm 0.00$ & $085.51 \pm 1.01^{b}$ \\
\hline $\mathrm{SB}_{3}$ & $44.00 \pm 0.30^{\mathrm{a}}$ & $00.00 \pm 0.00$ & $121.95 \pm 2.01^{a}$ \\
\hline $\mathrm{AB}_{4}$ & $40.36 \pm 0.34^{b}$ & $00.00 \pm 0.00$ & $074.97 \pm 1.31^{c}$ \\
\hline $\mathrm{AB}_{1}$ & $36.60 \pm 0.66^{c}$ & $00.00 \pm 0.00$ & $065.54 \pm 1.52^{d}$ \\
\hline \multicolumn{4}{|c|}{$\begin{array}{l}\text { High values are in bold and low values are underlined. The values of the same column affected by } \\
\text { different alphabetical letters are significantly different according to the Duncan test at the } 5 \% \\
\text { threshold; those affected by the same letter are not. Atadjon porridges AB1 }(1 / 3-2 / 3 \text {, } \\
\text { rice/tigernuts), AB4 ( } 1 / 2-1 / 2 \text {, rice/tigernuts), rice control RB2 (100\% rice) and tigernut control } \\
\text { SB1 (100\% tigernuts) }\end{array}$} \\
\hline
\end{tabular}

The oxalate contents varied from $21.90\left(\mathrm{RB}_{2}\right)$ to $44.00 \mathrm{mg} / 100 \mathrm{~g}\left(\mathrm{SB}_{3}\right)$ for the reference porridges. The atadjon porridges exhibited intermediate values of 36.60 $\left(\mathrm{AB}_{1}\right)$ and $40.36 \mathrm{mg} / 100 \mathrm{~g}\left(\mathrm{AB}_{4}\right)$, while the tannin content ranged from 65.54 $\mathrm{mg} / 100 \mathrm{~g}$ for $\mathrm{B}_{1}$ to $121.95 \mathrm{mg} / 100 \mathrm{~g}$ for $\mathrm{B} 3$, with intermediate values of 85.61 and $74.97 \mathrm{mg} / 100 \mathrm{~g}$ for $\mathrm{B}_{2}$ and $\mathrm{B}_{4}$, respectively.

\subsection{SENSORY CHARACTERISTICS OF THE DIFFERENT PORRIDGES}

\subsubsection{ACCEPTABILITY AND RANKING OF THE DIFFERENT PORRIDGES BY THE CONSUMERS}

The statistical analysis showed a significant difference $(p<0.05)$ on the acceptability of the different porridges by consumers. The results indicate that all the samples present a good acceptability in the terms of the sensory characteristics studied. Indeed, the acceptability scores vary from 3.09 to 3.83 Figure 2.

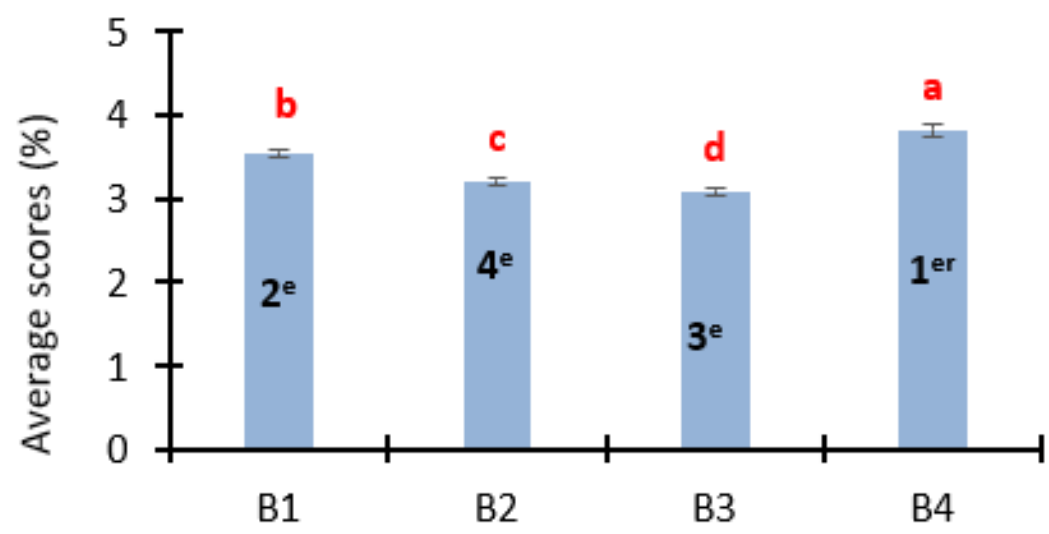

\section{Complementary porridges}

Figure 2 Acceptability and preference by ranking of the different porridges by tasters 
NB: B1: porridge AB1; B2: porridge RB2; B3: porridge SB3 and B4: porridge AB4 ; Atadjon porridges $\mathrm{AB} 1$ (1/3-2/3, rice/tigernuts), $\mathrm{AB} 4$ (1/2-1/2, rice/tigernuts), rice control $\mathrm{RB} 2$ (100\% rice) and tigernut control SB1 (100\% tigernuts)

However, the best scores are recorded by the atadjon porridge samples $\mathrm{AB}_{4}$ (3.83) and $A_{1}$ (3.55), which are therefore more appreciated than the other two reference porridges $\mathrm{RB}_{2}$ (3.21) and $\mathrm{SB}_{3}$ (3.09).

\subsubsection{ANALYSIS OF THE DESCRIPTIVE TEST OF THE STUDIED PORRIDGES}

The results of the descriptive test of the studied complementary porridges are depicted in the Figure 3.

These results indicate for the color descriptor, that the atadjon porridges recorded a light brown color intermediate between the white color of the rice control $\mathrm{RB}_{2}$ and dark brown of the yellow tigernuts control $\mathrm{SB}_{3}$. Similarly, in terms of the odor descriptor, both atadjon formulations exhibited an odor closer to that of the tigernut control $\mathrm{SB}_{3}$ with $\mathrm{AB}_{4}$ 's odor more pronounced. In the case of texture, note that all four porridges presented a low level of lumps with $\mathrm{AB}_{1}$ characterized by a less lumpy texture than the other porridges.

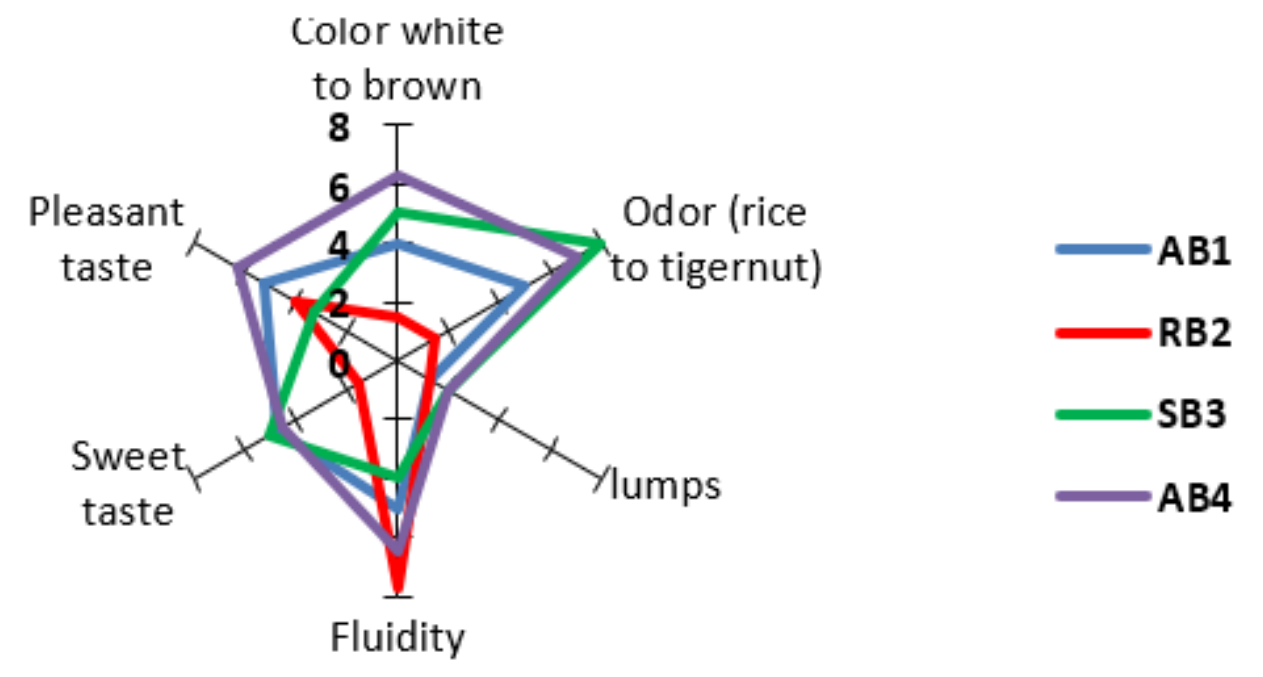

Figure 3 Average hedonic scores of the porridges attributed by the consumers

Regarding the appearance of the porridges, the atadjon formulations showed a more pronounced fluidity than the $\mathrm{SB}_{3}$ control. As for the taste descriptor, both atadjon porridges displayed a very pronounced sweet taste close to that of the $\mathrm{SB}_{3}$ yellow tigernuts control and they exhibited a pleasant taste compared to the $\mathrm{RB}_{2}$ and $\mathrm{SB}_{3}$ controls.

\subsubsection{PRINCIPAL COMPONENT ANALYSIS OF PORRIDGES}

The biplot of the principal component analysis showing the relationship between the different porridges and the sensory attributes is shown in Figure 4. 


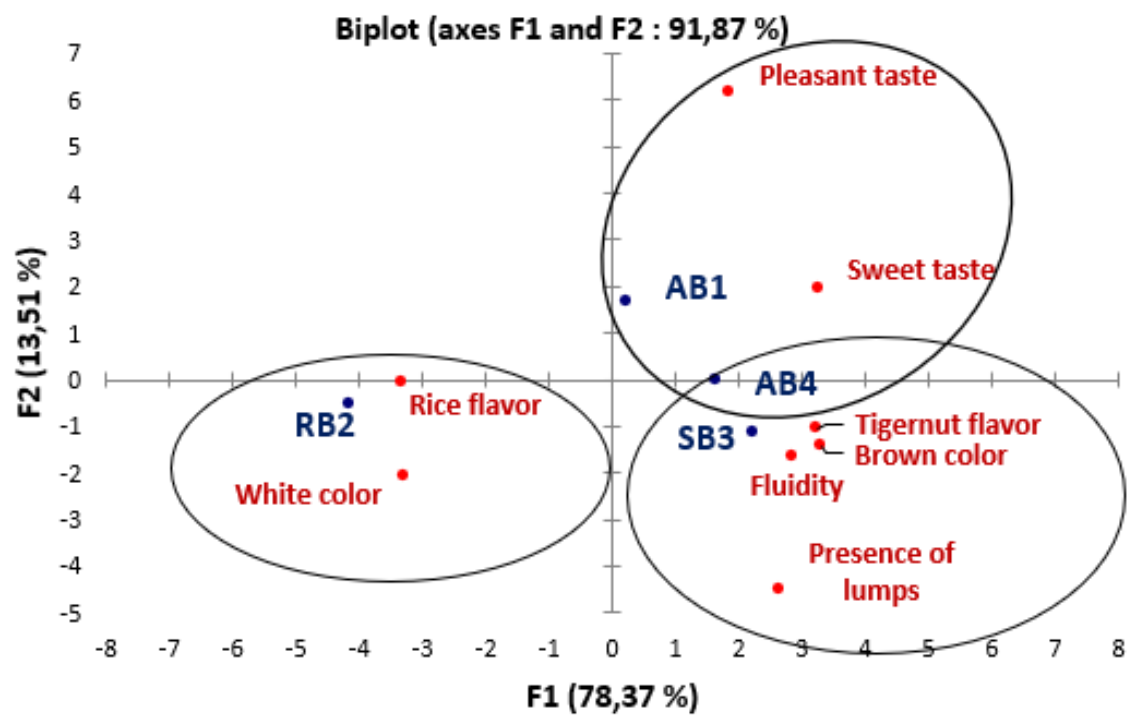

Figure 4 Principal Component Analysis showing the relationships between porridges and sensory attributes

This analysis showed that the F1 axis accounts for $78.37 \%$ of variation and allowed the separation of the tigernuts-based porridges $\left(\mathrm{AB}_{1}, \mathrm{SB}_{3}\right.$ and $\left.\mathrm{AB}_{4}\right)$ from the rice-based porridge $\mathrm{RB}_{2}$. While the $\mathrm{F} 2$ axis counting for $13.51 \%$ of variation has on the contrary allows to separate the controls $\left(\mathrm{RB}_{2}\right.$ and $\left.\mathrm{SB}_{3}\right)$ from the atadjon porridges $\left(\mathrm{AB}_{1}\right.$ and $\left.\mathrm{AB}_{4}\right)$.

It results from this study that the porridge atadjon $A_{1}$ was characterized by the descriptors pleasant taste and sweetness while the control porridge $\mathrm{SB}_{3}$ is associated with the descriptors tigernut aroma, brown color, presence of lumps and fluidity. The atadjon porridge $\mathrm{AB}_{4}$ is intermediate between $\mathrm{AB}_{1}$ and $\mathrm{SB}_{3}$ and finally, $\mathrm{RB}_{2}$ is entirely associated with the attributes white color and rice aroma.

\section{DISCUSSION}

During the first months of a child's life, physiological growth requires a higher energy and nutrient intake than adults FAO (2002). These needs are fully met by breastfeeding up to 6 months of age WHO (2003). After 6 months of age, breastfeeding alone is no longer sufficient and must be supplemented by a complementary food. Thus, considering the average level of breastfeeding observed in West Africa and the rhythm of three meals usually practiced in urban areas Trèche (2004), the complementary food used should be able to provide the missing elements in sufficient quantity and quality WHO (2003). This is to ensure the harmonious growth of these children.

Regarding energy density, the minimum required for healthy children receiving an average level of breastfeeding and three meals per day is $48 \mathrm{Kcal} / 100 \mathrm{~g}$ porridge (6-8 months) and $56 \mathrm{Kcal} / 100 \mathrm{~g}$ porridge (9-11 months) Trèche (2004). The two atadjon formulations recording energy density values higher than this minimum requirement could be more than sufficient to cover the energy needs of these children and ensure their normal physiological growth. Thus, the adoption of these atadjon formulations in the dietary habits of Ivorian families could help to ensure the coverage of the recommended energy needs since the main ingredient (tigernut) is a local, available and low-cost resource Koffi et al. (2005). 
However, it is important that the complementary food used in the diet of children aged 6 to 23 months, in addition to guaranteeing the recommended energy coverage also guarantees the required nutrient intakes WHO (2003).

Regarding protein, an essential nutrient in the fight against protein-energy malnutrition, the protein densities provided by the two formulations atadjon $A B_{1}$ and $A_{4}$ are higher than the minimum required (4.24 g/100 g porridge (6-11 months) Trèche (2004). These two atadjon formulations could therefore be recommended in the diet of children in urban areas where mothers are used to feeding them three meals a day Trèche (2004); FAO (2002). Protein is a major source of essential amino acids and energy in times of energy deprivation. Adequate dietary protein intake is essential for the maintenance of cellular function and integrity and for normalizing the health of infants and young children WHO (2003). Thus, atadjon formulations especially $\mathrm{AB}_{1}$ by its high protein and energy density could help avoid the problems of protein-energy malnutrition which is the most prevalent form of malnutrition in the world FAO (2002).

Similarly, with lipid densities above the minimum requirement of $2.7 \mathrm{~g} / 100 \mathrm{~g}$ WHO (2003) for children (6-11 months) receiving three meals per day, these two atadjon formulations, especially $A B_{1}$, could be recommended to parents for the feeding of their weaning age children. Indeed, such formulations will provide the essential fatty acid requirements necessary for brain development and maturation of neurosensory functions in young children FAO (2002). In addition, the ingredients of these tuber-cereal formulations are local food resources that are available at a lower cost. Thus, the adoption of these formulations in the dietary habits would be beneficial for low-income families. They could help them to meet their children's energy and nutrient needs adequately and at lower cost Trèche (2004).

It is also important that the required mineral density of the supplemental foods be met to ensure that the target children thrive. Thus, the atadjon formulations overall increased mineral densities compared to the reference porridges. However, the density of the studied minerals overall increased in the $\mathrm{AB}_{1}$ formulation except for Ca compared to the $\mathrm{SB}_{3}\left(100 \%\right.$ tigernut) control porridge. While the atadjon $\mathrm{AB}_{4}$ formulation caused a decrease in the level of studied minerals except for $\mathrm{P}$ and $\mathrm{Mg}$. As a result, the $A B_{1}$ formulation which allows to significantly increase the mineral potential of the porridges appears more interesting than the $\mathrm{AB}_{4}$ formulation. In addition, the minimum required densities of $\mathrm{Fe}(5$ and $3 \mathrm{mg} / 100 \mathrm{~g}$ porridge) and $\mathrm{Zn}$ ( 2 and $1.25 \mathrm{mg} / 100$ g porridge), for children aged 6-8 months and 9-11 months, respectively receiving three meals per day are achieved with both formulations of porridge atadjon. This sufficient intake of these essential trace minerals is crucial for these children. Indeed, Zinc is involved in many physiological functions such as carbohydrate, lipid and protein metabolism Hambidge (2000). Similarly, Fe plays an essential role in many vital functions such as oxygen transport and storage Yip (2000) . Any deficiency in these minerals will result in stunted mental and intellectual development in young children and stunted growth for Fe and $\mathrm{Zn}$, respectively FAO (2002).

Low fiber content in complementary foods is recommended to reduce bulkiness and facilitate digestibility and nutrient absorption Olorunfemi et al. (2006). Thus, fiber contents below the $5 \mathrm{~g} / 100 \mathrm{~g}$ limit FAO (1991) in atadjon formulations could contribute to better nutrition of young children. In Africa, carbohydrates consisting mostly of starch are the main nutrients in complementary foods for young children Trèche (2004). As such, they are the main source of energy in these foods. $\mathrm{The} \mathrm{AB}_{1}$ formulation with the highest carbohydrate content would therefore be recommended for the diet of weaning-age children. Indeed, its 
integration into the dietary habits of these children could help ensure the maintenance of a good level of intake of this nutrient.

According to Caplice and Fitzgerald (1999), the high organic acid content would account for the observed decrease in porridge $\mathrm{pH}$. In addition, these acidic $\mathrm{pH}$ values are within the range of 4.0-4.5 pH of hygienic and safe foods WHO (1998) . Thus, the acidity of these atadjon porridges may provide some ability to limit the growth of pathogenic and/or spoilage microorganisms.

Sweetness has been widely shown to be the most preferred flavor in neonates and young children and has a positive effect on their appetite Finlayson and Bundell (2008). Thus, atadjon formulations, especially $A_{B} B_{1}$, with high total sugar contents could modulate children's appetite by influencing their eating motivation.

Anti-nutrient compounds such as phytates, tannins and oxalate interfere with the assimilation of nutrients. This is of particular concern in young children where the irreversible consequences can lead to developmental deficiencies FAO (2002). Under these conditions, the absence of phytates and the low oxalate contents (compared to control $\mathrm{SB}_{3}$ ) in atadjon formulations are a major advantage because the uncomplexed bivalent elements will be bioavailable to these children. Similarly, the low tannin contents of the atadjon formulations compared to those of the control porridges would play in favor of their inclusion in the complementary diet of young children. Indeed, tannins are known to reduce the availability of proteins, carbohydrates and minerals by forming a non-digestible complex with these nutrients Nnam and Obiakor (2003). The reduced level of tannin could therefore improve the availability of these nutrients.

Sensory analysis of the atadjon porridges indicated that they were well liked by the panel. The panel's preference was for both atadjon formulations with a clear preference for the $A_{4}$ formulation (1st) followed by $A_{1}$ (2nd). The differences observed in the appreciation of the porridges could be significantly influenced by the degree of combination of ingredients, as well as the novelty of the products Soro et al. (2013) .

In the descriptive test, tasters overwhelmingly rated the atadjon porridges as good quality because they had a light brown coloring, sweet taste, less pronounced odor of tigernuts, smooth texture, and fluid appearance. All these criteria leading to a pleasant taste of these porridges in the mouth.

\section{CONCLUSION}

As prepared, atadjon porridges $\left(\mathrm{AB}_{1}\right.$ and $\left.\mathrm{AB}_{4}\right)$ have energy and nutritional densities (in macro and micro elements) higher than the values recommended for children with an average level of breastfeeding and receiving an average of three (03) meals a day. The relatively low content of anti-nutritional factors allows for a good bioavailability of minerals and certain biomolecules that are essential for the harmonious growth of infants. However, it is advisable to consider formulations with other nutritious condiments in order to obtain nutritious supplemental porridges whatever the level of breastfeeding and the number of meals. This will truly contribute to the recommended nutritional intake regardless of the living conditions, especially in rural areas where women do not have the possibility to ensure three daily meals.

\section{ACKNOWLEDGEMENTS}

Special thanks to Dr. Zoué for his guidance in the execution of this work and his support in the writing of this manuscript. 


\section{REFERENCES}

A. Ruwaida, P. Kirthee, S. Mathulisi and K. Unathi. (2016) "Accepatance of a complementary food based on pro-vitamin A- Biofortified maize and chicken stew. Journal of Human Ecology, vol 55, n 3, pp. 152-159, Retrieved from https://doi.org/10.1080/09709274.2016.11907019

A. Toledo, and B. Burlingame. (2006) "Biodiversity and Nutrition : A Common Path toward Global Food Security and Sustainable Development". Journal of Food Composition and Analysis, vol 19, pp. 477-483, Retrieved from https://doi.org/10.1016/j.jfca.2006.05.001

AOAC Association of Official Analytical Chemists. (2005) "Determination of Moisture content, Fat content, Ash content, Protein content and Fibre content in Foods using". Official Method no. 925.10, 2003.05, 923.03, 960.52 and 962.09 respectively ;

AOAC Offic ial Methods of Analysis. (1990) "15th Edition, Association of Official Analytical Chemists". Washington DC, vol 808, n 831, pp. 835-1113,

AOAC. (1980) "Official methods of analysis, 13th ed, Association of Officiel Analytical Chemists". Washington, DC, USA, pp. 376-384,

B. L. Koffi, G. J. Nemlin, S. Lefevre and A. Kamenan. (2005) "Caractérisation physicochimique et potentialités thérapeutiques du pois sucre (Cyperus esculentus L. CYPERACEAE) ". Agronomie Africaine, volume 17, nº 1, pp. 6371, Retrieved from https://www.ajol.info/index.php/aga/article/view/1658

C. Dolan, M. Mwangome, T. Khara. (2015) "Extent of stunting and wasting in the same children. Panel in global nutrition report : Actions, accountability to advance nutrition sustainable development". International Food Policy Research Institute, pp. 102-108,

C. Victora, R. Bahl, A. Barros, G. Franca, S. Horton, J. Krasevec, S. Murch, M. Sankar, N. Walker, N. Rollins. (2016) "Breastfeeding in the 21s Century : Epidemiology, Mechanisms, and Lifelong Effect". Lancet, vol 387, n¹0017, pp. 475-490, Retrieved from https://doi.org/10.1016/S0140-6736(15)01024-7

E. Caplice and G. F. Fitzgerald. (1999) - Food fermentations : role of microorganisms in food production and preservation. International journal of food microbiology, vol 50, pp. 130-149, Retrieved from https://doi.org/10.1016/S0168-1605(99)00082-3

FAO / WHO /UNU. (2002) "Protein and amino acid requirements in human nutrition". WHO technical report, series $\mathrm{n}^{\circ} 935,284 \mathrm{p}$.

FAO. (2002) "Food energy-methods of analysis conversion factors". FAO Ed, Rome, $97 \mathrm{p}$,

FAO/WHO. (2002) "Iron. In : Human vitamin and mineral requirements", Report of a joint FAO/WHO expert consultation, Bangkok, Thailand, pp 195-222,

FAO/WHO. (1991) Protein quality evaluation. 72 p.

Hambidge. (2000) "Human zinc deficiency". Journal of Nutrition, vol 130 (5S suppl), pp 1344S-1349S, Retrieved from https://doi.org/10.1093/jn/130.5.1344S

J. Folch, M. Lees, et G. H. Sloane Stanley. (1957) "A simple method for the isolation and purification of total lipids from animal tissues". Journal of Biological Chemistry, vol 226, pp. 497-509, Retrieved from https://doi.org/10.1016/S0021-9258(18)64849-5 
J. P. H. Linssen, G. M. Kielman, J. L. Cozijnsen and W. Pilnik. (1988) "Comparison of chufa and olive oils". Food Chemistry, vol 28, pp. 279-285, Retrieved from https://doi.org/10.1016/0308-8146(88)90103-3

K. R. Azagoh, J. Enoh, B. Niangue, L. Cissé, S. Oulai, J. Andoh. (2013) "Connaissances et pratiques des mères d'enfants de 6 à 18 mois relatives à la conduite du sevrage : cas de l'hôpital général de Marcory". Mali médical 2013 : Tome XXVIII, $\mathrm{n}^{\circ} 4$,

M. A. Belewu and K. Y. Belewu. (2007) "Comparative physicochemical evaluation of tigernut, soybean and coconut milk sources". International Journal of Agriculture and Biology, vol 5, pp. 785-787, Retrieved from https://d1wqtxts1xzle7.cloudfront.net/43323523/convert-jpg-topdf.net_2016-03-03_20-40-15-with-cover-page-

v2.pdf?Expires=1641801874\&Signature=WLAE8ucuuyhyJ20RE8qwRjGz1t XxKBUwlk2 yPTfuXlV6ZjR xz6i4FIo1GFrVBstskuZZSCJjWHTwfzqit0sTzN iTNUbJYNcm4D5zE5JHjXjUGM2oMqaYEfWWcJlFauev6MIPrPA6ntKZ1WIx bH876GHAAHbbNpmBWfkA8JjXYTHeTdwaO2knHzOgkLTpmojBJDXeELoT hH9rGIX4VJ8paUVOqANUaGlE8 qy8D4-

th1PwQUnmM7LBkhtcrmNdi2UQW3YxDI2sDuTErI1kis0mq1FVXZQEflGC 2-vjfkSI1AJXg0acTabJ11a3UcGLBVR1YjqZMW1L23IeJR w3TQ_\&KeyPair-Id=APKAJLOHF5GGSLRBV4ZA

M. C. Meilgaard, V. Civille and T. Carr. (2007) "Sensory evaluation techniques", 4th edition Boca Raton. CRC press, Retrieved from https://doi.org/10.1201/b16452

M. Dubois, K. A. Gilles, J. K. Hamilton, F. A. Roben et F. Smith. (1956) "Colorimetric method for determination of sugar and related substances. " Analytical Chemistry, Vol 28, pp. 350-356, Retrieved from https://doi.org/10.1021/ac60111a017

M. S. Defelice. (2002)"Yellow nutsedge Cyperus esculentus L.-Snack food of the gods". Weed Technology, vol 16, n 4, pp. 901-907,

https://doi.org/10.1614/0890-037X(2002)016 [0901 : YNCELS]2.0.CO ;2

N. G. Agbo, M. Uebersax and G. Hosfield. (1985) "An efficient extraction technique of sugars from dry edible beans (Phaseolus vulgaris and estimation an HPLC". Université nationale de Côte d'Ivoire Annales série C. (Sciences) Tome XXI, $10 \mathrm{p}$,

N. Nnam and P. Obiakor. (2003) "Effect of fermentation on nutrient and antinutrient composition of baobab (Adansonia digitata) seeds and rice (Oryza sativa) grains". Ecology of Food and Nutrition, vol 42, pp. 265-277, Retrieved from https://doi.org/10.1080/03670244.2003.9657684

0. Olorunfemi, F. Akinyosoye and F. Adetuyi. (2006) Microbial and nutritional evaluation of infant weaning food from mixture of fermented food substrates. Research Journal of Biotechnological Science, vol 1, pp. 20-23,

O. Y. Mogaji. (2016) "Use of chufa (Cyperus esculentus) tubers as a nutritional additive to the diet of common carp (Cyprinus carpio) fingerlings". Master of sciencein biochemistry. PUNJAB agricultural university ludhiana, 64p,

R. A. Day and A. L. Underwood. (1986) "Quantitative analysis (5thed.) ". Prentice, Hall publication, pp 701,

R. Black, C. G. Victora, S. P. Walker, Z. A. Bhutta, P. Christian, M. Ezzati, S. GranthamMcGregor, J. Katz, R. Martorell and R. Uauy. (2013) "Maternal and child undernutrition and overweight in lowincome and middle-income 
countries". Lancet, vol 382, $\mathrm{n}^{\circ}$ 9890, pp. 427-451, Retrieved from https://doi.org/10.1016/S0140-6736(13)60937-X

R. N. Finlayson and J. Bundell. (2008) "The role of implicit wanting in relation to explicit liking and wanting for food : implications for appetite control". Epub 2007 Jun 28, vol 50, $\mathrm{n}^{\circ} 1$, pp. 120-127, Retrieved from https://doi.org/10.1016/j.appet.2007.06.007

R. Yip. (2000) "Significance of an abnormally low or high hemoglobin concentration during pregnancy: special consideration of iron nutrition". American Journal of Clinical Nutrition, vol 72, pp. 272 - 279, Retrieved from https://doi.org/10.1093/ajcn/72.1.272S

S. Soro, G. Konan, E. Elleingand, D. N'guessan, and E. Koffi. (2013) "Formulation d'aliments infantiles à base de farines d'igname enrichies au soja". African Journal of Food agriculture nutrition and development, vol 3, n 5, pp. 83138339, Retrieved from https://doi.org/10.18697/ajfand.60.12655

S. Trèche. (2004) "Les voies alimentaires d'une meilleure nutrition". Sciences au Sud, janvier-Février 2004, n²3 : 2. IRD : sciences-au-sud - n-23-janvierfevrier-2004,

S. Trêche, J. Massamba, G. Gallon, A. Cornu. (1993) "Utilisation and nutritive value of traditional weaning gruels in rural Congo". Communication affichée présentée au XVème congrès International de Nutrition, Septembre 1993, Adélaïde (Australie),

V. L. Singleton, R. Orthofer and R. Lamuela-Raventos. (1999) "Analysis of total phenols and other oxydant substrates and antioxydants by means of Folinciocalteu reagent". Methods in Enzymology, vol 299, pp.152-178, Retrieved from https://doi.org/10.1016/S0076-6879(99)99017-1

W. O. Atwater, F. G. Benedict. (1902) "Experiments on the metabolism of matter and energy in the human body, 1898-1900. US Office of Experiment". Stations Bulletin, n¹09, Government Printing Office, Washington DC, Retrieved from https://doi.org/10.5962/bhl.title.123031

WHO/UNICEF. (2003) "Global Strategy for Infant and Young Child Feeding". Retrieved from http://apps.who.int/iris/bitstream/handle/10665/42590/9241562218.p df

WHO/UNICEF. (1998) Complementary feeding of young children in developing countries : A review of current scientific knowledge. UNICEF/University of California-Davis/WHO/ORSTOM, Geneva : WHO/NUT/98. 1,

Z. Bainbridge, K. Tomlins and A. Westby. (1996) "Analysis of condensed tannins using acidified vanillin". Journal of Food Science of Agriculture, vol 29, pp. 77-79, 